Journal of Association of Arab Universities

for Tourism and Hospitality (JAAUTH)

Vol. 20 No. 3, (2021), pp.1-14.

journal homepage: http://jaauth.journals.ekb.eg

\title{
Body Language of the Holy Virgin Mary in Coptic Iconography
}

Ahmad Mohamed Khalaf

Faculty of Tourism and Hotels, Minia University

\section{ARTICLE INFO}

Keywords:

Body language; nonverbal

communication; the

Holy Virgin; Coptic iconography.

\section{(JAAUTH) \\ Vol. 20, No. 3, (2021), PP.1-14.}

\section{ABSTRACT}

The Holy Virgin Mary has always been an inspiration to iconographers and sculptors through ages. She is widely represented in Coptic art in themes like the annunciation, the nativity, the crucifixion, the flight to Egypt, and the entombment. In such paintings, the Holy Virgin is shown with varied facial and physical gestures, denoting different meanings. Yet her body language changes from a scene to another. The iconographical themes of the Holy Virgin are drawn from the narrations of the Holy Book and sometimes the interpretations of the church fathers. The artists executed the iconographical themes associated with the Holy Virgin Mary based on their understanding of the biblical text, their culture background, and the surroundings. This paper focuses on the interpretation of the body language or the non-verbal communication of the Holy Virgin Mary in Coptic iconography. It attempts to classify Her different poses, gestures, and clothes.

\section{Introduction}

The study of the body language in antiquity has attracted the attention of scholars, who also considered is not less important than studying the styles of arts and aspects of the human body. ${ }^{1}$ Non-verbal actions were not made in vain or randomly selected. They were meant to expose, among other things, the social class of the individuals and give informative data such as gender, position, social status, and other surrounding circumstances. ${ }^{2}$

Body language is defined as a movement of a body or a part of a body to reflect a meaning of a person. It influences a motivation and a concept. ${ }^{3}$ Understanding the meaning of the gesture can reflect the individual's felling at a moment. Universal

\footnotetext{
${ }^{1}$ J. Eugene Botha, "Exploring Gesture and Nonverbal Communication in the Bible and the Ancient World: Some Initial Observations," Neotestamentica, Vol. 30, Issue 1, (December 19960, 4.

${ }^{2}$ Enid Schildkrout, "Body Art as Visual Language," AnthroNotes, Vol. 22, (Winter 2001), 1.

3 David B. Givens, The Nonverbal Dictionary of Gestures, Signs and Body Language Cues, (Washington: Center for Nonverbal Studies Press, 2002), 8.
} 
gestures such the gestures expressing happiness, sadness, and fear are well-known and accepted in the world, but other gestures differ from one culture to another. ${ }^{1}$

It is nowadays much easier to interpret the gestures in contrast of interpreting gestures historically. In accordance with social and cultural differences, different readings were given for non-verbal communication. Exploring body language in antiquity requires a good read of the text allowed, surrounding condition, ancient cultures, societies and gesture inside the whole context. ${ }^{2}$

Body language includes the facial features expressions, physical body movements, and clothing indications. Facial features include signals of the head and gestures of the eyes and mouth. The human has many parts of a body such as arms, hands, and legs, which can be employed in body language. Each part expresses a feeling. Probably, the most expressive parts of the body are the hands since they give the nerve connection than any other part of a body. ${ }^{3}$ Clothing may also indicate the social and economic status. To give the best interpretations for the feeling, one should not depend on a specific gesture, as sometimes persons used one action to reveal a feeling and sometimes two actions or more. ${ }^{4}$

\section{Exploring the Body Language of the Holy Virgin}

The Holy Virgin is largely depicted in different subjects and attitudes in Coptic art such as the annunciation, the nativity, the escape to Egypt, Hodgetria, crucifixion, entombment, and many other subjects. ${ }^{5}$ These depictions are applied on miscellaneous materials like wood, metal, stone, and others. She is mostly depicted in wall paintings and icons. ${ }^{6}$

The Coptic iconographer inspired the ideas of painting Christian subjects from the Holy Book, New Testament, and the church fathers' interpretations. Depending on how the iconographer reads and recognizes the topic, it is quite natural that the depictions differ and vary. The execution of Christian paintings also depends on the culture and available tools and capabilities of the iconographer and universal gestures and the vision of iconographer at the time of painting.

The Holy Virgin is chosen to be the topic of this article because the features of Her body language are clearer than other divine or sacred personalities and differ in themes. She is exposed with different feelings such as surprise, fear, sadness, obedience, and love.

This paper deals with fourteen figures varying in date, reflecting eight themes from the various stages of the Holy Virgin life. All the chosen scenes are applied on wall

\footnotetext{
${ }^{1}$ Allan and Barbara Pease, The Definitive Book of Body Language, (London: Orion Media Press, 2004), 11.

${ }^{2}$ Botha, "Exploring Gesture,", 1.

${ }^{3}$ Givens, The Nonverbal Dictionary, 5.

${ }^{4}$ Pease, The Definitive Book of Body Language, 20-21.

${ }^{5}$ Pierre Du Bourguet, "Christian Subjects in Coptic Art," in Coptic Encyclopedia, ed. Aziz S, Atiya (New York: Macmillan Publishing Company, 1991), Vol. II, 526-544.

${ }^{6}$ Sherin Sadek El Gendi, "Different Attitudes of The Holy Virgin Mary In Coptic Art," دراسات في آثار الوطن العربي, Vol.13, Issue 13, (2010), 38-66.
} 
paintings and icons, from the Syrian monastery, the Hanging Church in Old Cairo, and Bawit. They are preserved in Coptic Museum in Old Cairo, Saint Barbara Church, the Hanging church in Old Cairo. Moreover; preserved in The Holy Virgin Church in Maadi, the Holy Virgin Church in Gebel al Tier, the Archangel Michael Monastery in Mallawi, Mar Mina church in Sanabu, and the church of Abu Saiefien in Akhmim.

\section{- Gestures of surprise and anxiety}

The annunciation incident was narrated in the Holy Book, New Testament. It is specifically mentioned in Luke, Chapter one, verses 26: 34, and in Mathew chapter one, verses 20: 25. The text describes the Holy Virgin's wondering and troubling feelings of the speech of the Angel of the Lord, while the angel tries to reassure Her. ${ }^{1}$ The iconographer understood the text well and tried to express the Virgin's feelings to show the idea with his tools.

Mary appears in the scene in a standing posture. ${ }^{2}$ She upraised her right hand towards her chin. The left hand is set beside her body. She fixes her gaze to the ground. Her legs are aligned beside each other. Her head is surrounded with the halo. Angel of the Lord approaches and seems to talk to her. She appears standing in a level lower than the Angel (Fig.1).

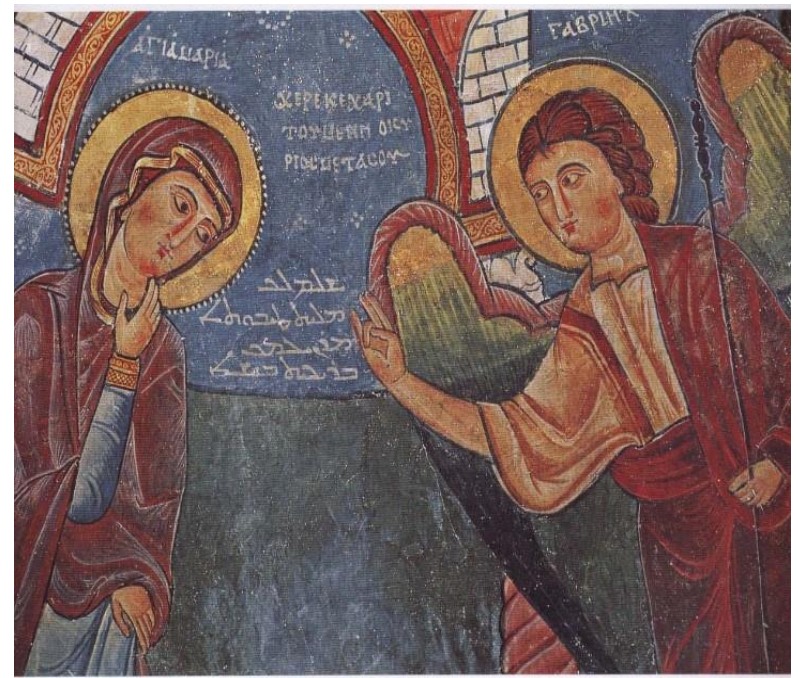

Fig.1. Annunciation of the Holy Virgin, Syrian Monastery, after (Zibawi 2003, 133).

Through reading the text and watching the themes, the gestures could be interpreted. Gesture of pulling the head down can be interpreted as the Holy Virgin is listing to a speaker or may admiring his speech. Also, this gesture may happen while subordinators are approached by superiors as a kind of respect. Moreover, it shows

\footnotetext{
${ }^{1}$ Holy Book, New Testament, Luke 1: 26- 34, Mathew 1: 20-25.

${ }^{2}$ Syrian monastery located in Natrun Valley. It was built by the Copts in the sixth century. It was named after the Syrian monks who were dowelled in during the ninth century. See: Hugh G. Evelyn White, The Monastries of Wadi 'N Natrun: Architecture and Archaeology, Part II, (New York: MCMXXXIII Publisher, 1932), 309.
} 
the power play between persons. ${ }^{1}$ The gesture of the right hand cannot be neglected as one of the gestures expresses Her surprise.

The same theme is applied on the icon preserved in St. Barbara Church in Old Cairo; the Holy Virgin is depicted standing to the left side of the Angel. ${ }^{2}$ Most of gestures are similar to the previous scene, except for some little gestures. She upraises her hand in front of her chest with open palm towards the angel. Her left hand is beside her body and holds a book (Fig. 2).

The gesture of upraising the hand in the scene can be understood as she replies the greeting of the Angel politely. If the palm of the right hand is set towards her body, it can totally provide another interpretation, namely the fear of speech. The most expressive gesture in the scene is also the direction of the head towards the ground, allowing whoever looks to the Virgin's figure would realize that she is very astonished.

Both scenes vary in date; the first dates to the thirteenth century and the other dates to the eighteenth century. Yet both iconographers used mostly the same non-verbal signs with little differences. They used the opened right palm hand; the first is shown near her chin and the second is depicted in front of Her chest. The same head direction is applied with the eyes looking down. The color of the gown is different, while the blue color dress is used in both scenes.

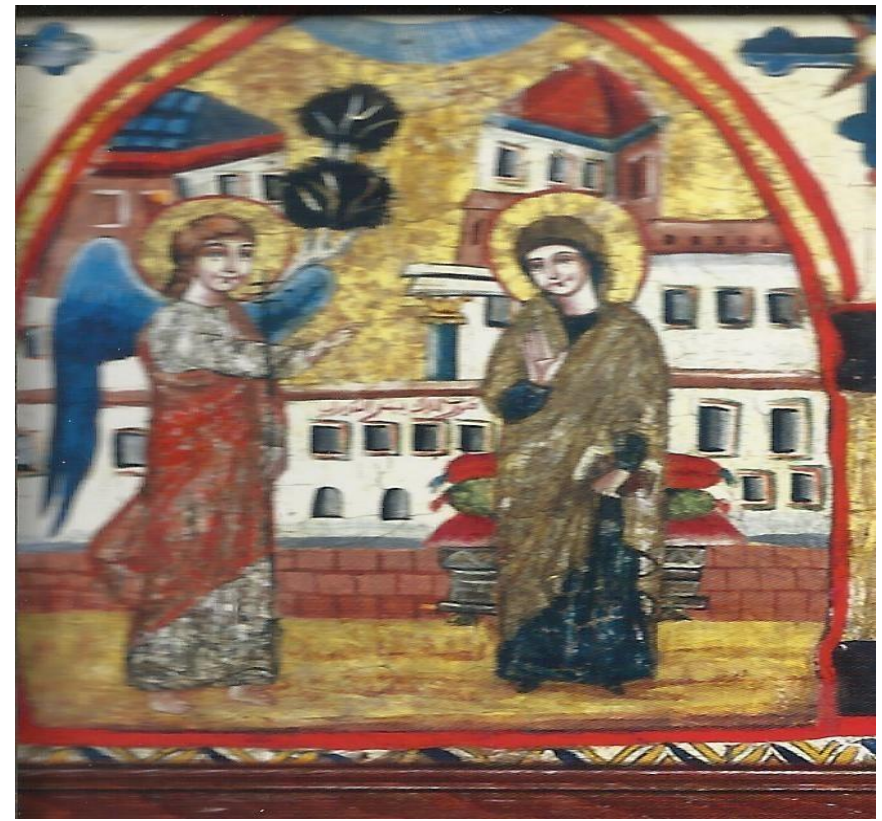

Fig.2. Annunciation, detail of Nativity Icon, Church of St. Barbara, Old Cairo, $18^{\text {th }}$ CE, after; (Gabra and Van Loon 2007, 121)

\footnotetext{
${ }^{1}$ Pease, The Definitive Book of Body Language, 235.

${ }^{2}$ Church of St. Barbara was founded by Athansius of Edessa, scribe of Abd El Aziz Ibn Marwan in 685- 705. It locates in Old Cairo district. See; Gabra and Van Loon, The churches of Egypt, 120.
} 


\section{- Gestures of Fear}

The nativity event is documented in the gospel of Luke, chapter two, verses eight to twenty. It is also narrated in the gospel of Mathew, chapter one, verses eighteen to twenty-four. The interpretations of the church Fathers agree that the birth of Jesus took place in hard circumstances in a manger. ${ }^{1}$

Coptic iconographers show different non-verbal communications of the Holy Virgin in the nativity scenes. Signals made in the nativity scenes depict the Holy Virgin putting Her left hand on her left knee. Her right opened palm hand is placed on her chest. Her head is looking away from the infant Jesus (Fig. 3). Placing the hand over the chest with an open palm is often interpreted as feeling of fear. The scene of looking away from the infant Jesus may express uncomforted feelings.

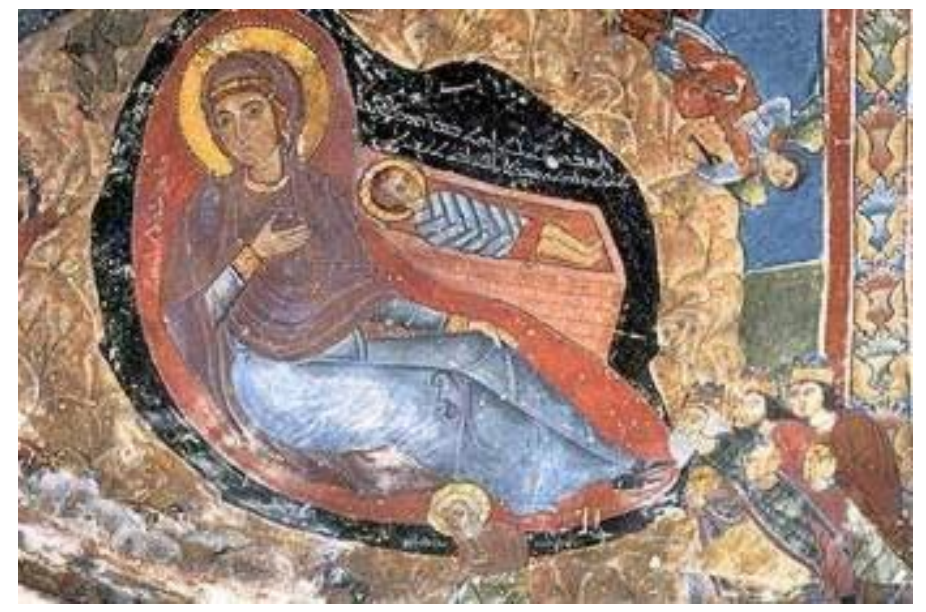

Fig.3. Nativity of the Holy Virgin, Syrian Monastery, after; (Zibawi 2003, 131).

\section{- Gestures of warning}

The nativity scene is shown in the Hanging Church in Old Cairo district. The Holy Virgin is represented lying on a back. Her left hand is rested upon her knee. The right one is pointing to a woman with index finger in a vertical pose. Her head leans towards the figure beside Her while Her eyes are not looking to her. The infant Jesus is placed a little far from the Holy Virgin (Fig. 4).

To give a good exploring for the gestures of the Holy Virgin in this scene that is different than the whole nativity scenes. This account is narrated in the apocryphal Gospel of James Chapter twenty. Salome is shown beside the Holy Virgin, who suspects the Virginity of Mary. Then she asked forgiveness of God for her action. ${ }^{2}$ Pointing with index finger in non-verbal communication refers to do or not to do. ${ }^{3}$ The iconographer wants to express the warning of the Holy Virgin to Salome. The rest gestures refer to the fear and anxiety of the Holy Virgin Mary.

\footnotetext{
${ }^{1}$ The Holy Book, New Testament, Luke 2: 8-20, Mathew 1: 18-24.

${ }^{2}$ Markus Bockmuehl, Ancient Apocryphal Gospels (Louisville, Kentucky: Westminster John Knox Press, 2017), 58.

${ }^{3}$ Pease, The Definitive Book of Body Language, 38.
} 


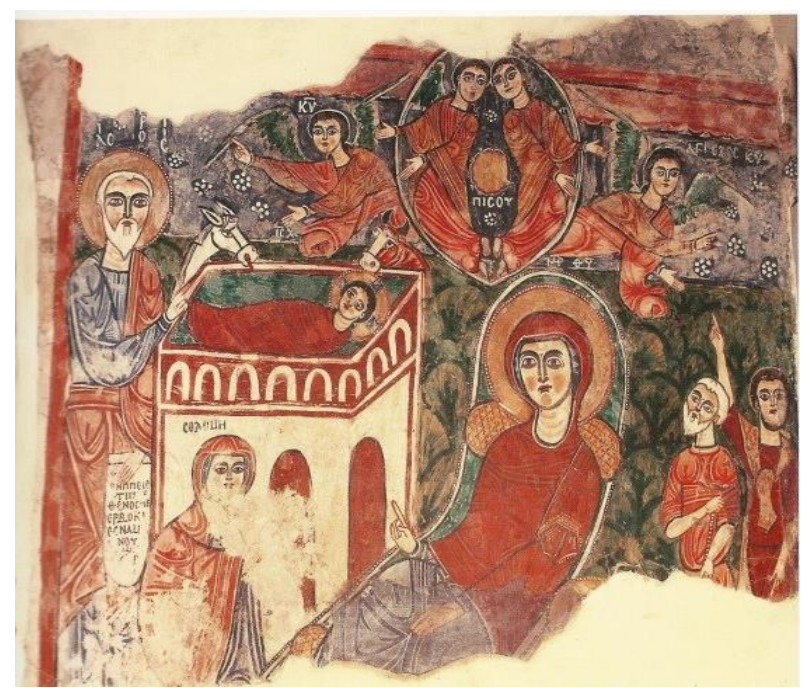

Fig.4. Nativity, $13^{\text {th }}$ CE, Hanging Church, Old Cairo. After; (Gabra and Van Loon 2007, 116)

\section{Gestures reflect the motherhood feelings}

The Virgin Hodegetria refers to the Holy Virgin and the Child depiction. Bawit Niche preserved in the Coptic Museum depicts the Holy Virgin and the Child. She sits on a throne above a pillow. She holds the infant Jesus on her left leg. She holds the child with her both hands. She is looking frontally. Her facial features appear with oval face, wide eyes and small mouth. Her neck is exposed (Fig. 5).

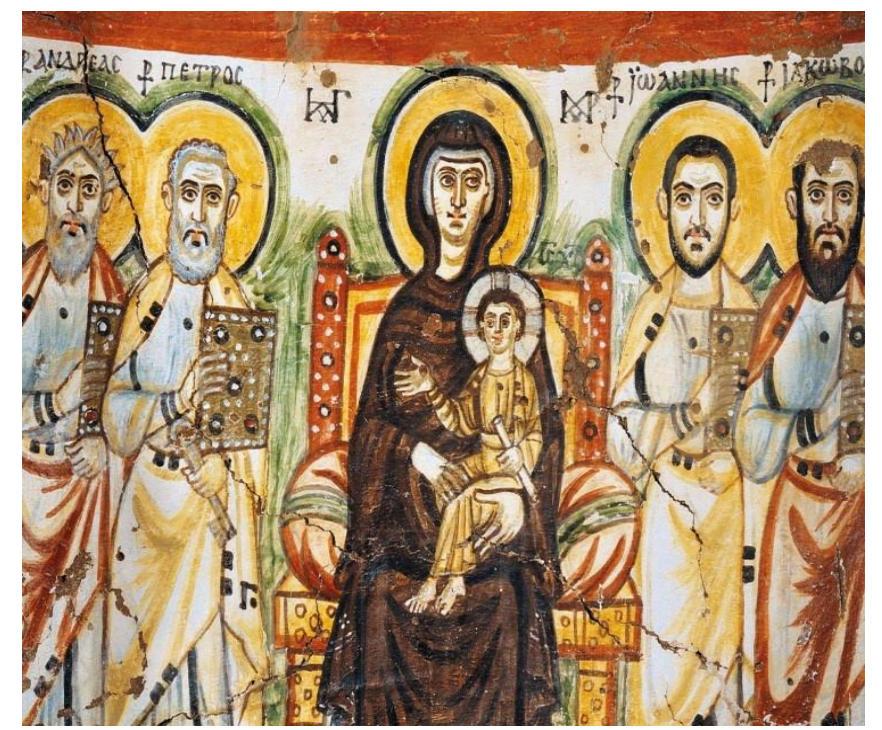

Fig.5. Niche of Bawit, preserved in Coptic Museum, Old Cairo. After; (Gabra and Eaton-Krauses 2007, 97)

The same subject is applied on the icon preserved in the Holy Virgin Mary Church in Maadi. The Holy Virgin holds the infant Jesus on the right side, with both hands. Her head leans to the right side towards the Child. She fixes her sight on Him. Tilting the head to one side may denote a submission signal. This gesture makes the throat and 
the neck exposed that give less threating and less impression. That was originated in a child posture, while resting his head over his parent's chest or shoulder (Fig. 6). ${ }^{1}$

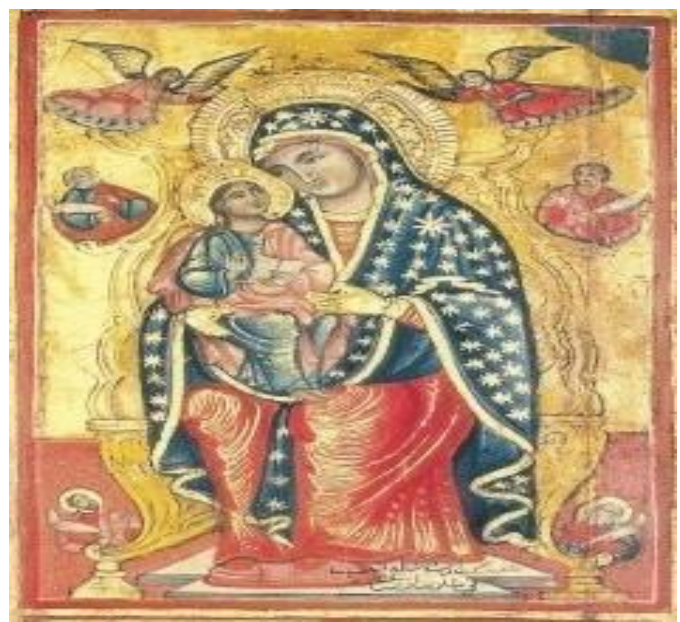

Fig.6. Detail of Hodgetria icon, Holy Virgin Mary Church in Maadi. After; (Gabra and Van Loon 2007, 195)

\section{- Gestures of sadness during Crucifixion}

The four Gospel accounts narrated the crucifixion incident and mentioned presence of the Holy virgin. This incident was inspirational for the iconographers through ages. They try to express the non-verbal communication of the people who witnessed the incident. $^{2}$

The Icon of crucifixion in the monastery of Gebel El Tier in Minia represents the Holy Virgin in a standing posture. Her both hands are closed over her chest; the right one is placed over the left hand. She raised her head towards the crucified Jesus and looks at Him (Fig. 7).

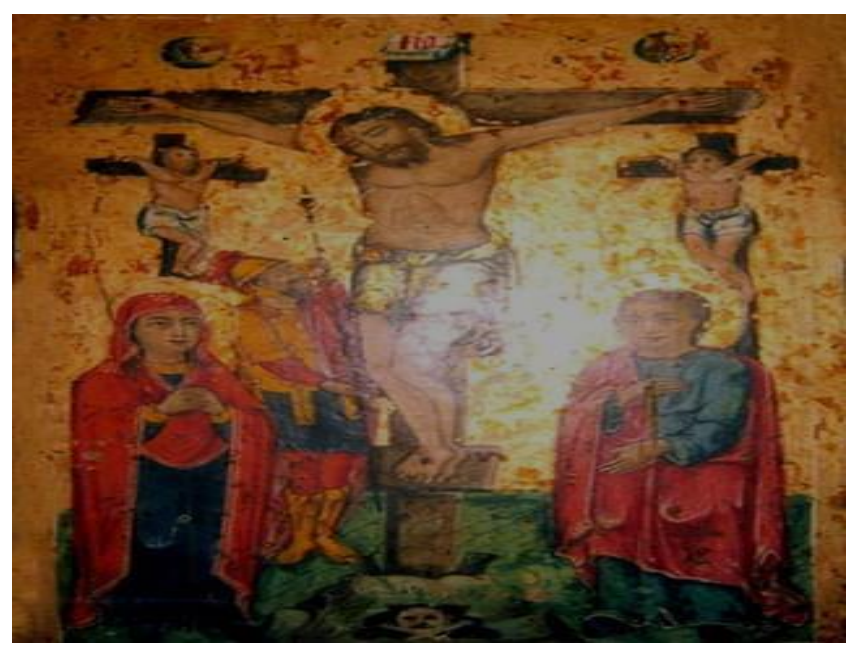

Fig.7. Crucifixion, Gebel Al Tier, Samalout, Al Minia.Taken by the author@ Ahamd Khalaf.

\footnotetext{
${ }^{1}$ Pease, The Definitive Book of Body Language, 233.

${ }^{2}$ Mathew 27: 32-56, Luke 23: 39-43, Mark 15: 21-32, John 19: 1-25.
} 
Both gestures of the clenched hands and the head reflect anxiety, tension, and fear. Moreover, her facial features with the small closed mouth refer to deep sad feeling. Also, the clenched hands over the body gesture express restrained, anxious, and negative feelings.

Another icon showing the same notion is preserved in Mar Mina Church in Sanabu village, Asyut. It shows the Holy Virgin with other gestures as she appears in a standing pose; she holds along white handkerchief with her left hand and tries with right hand to dry her tears. Her facial features represent her with crying eyes and narrower eyebrows. The iconographer succeeded in expressing deep sad feelings with facial features and hands gestures (Fig. 8).

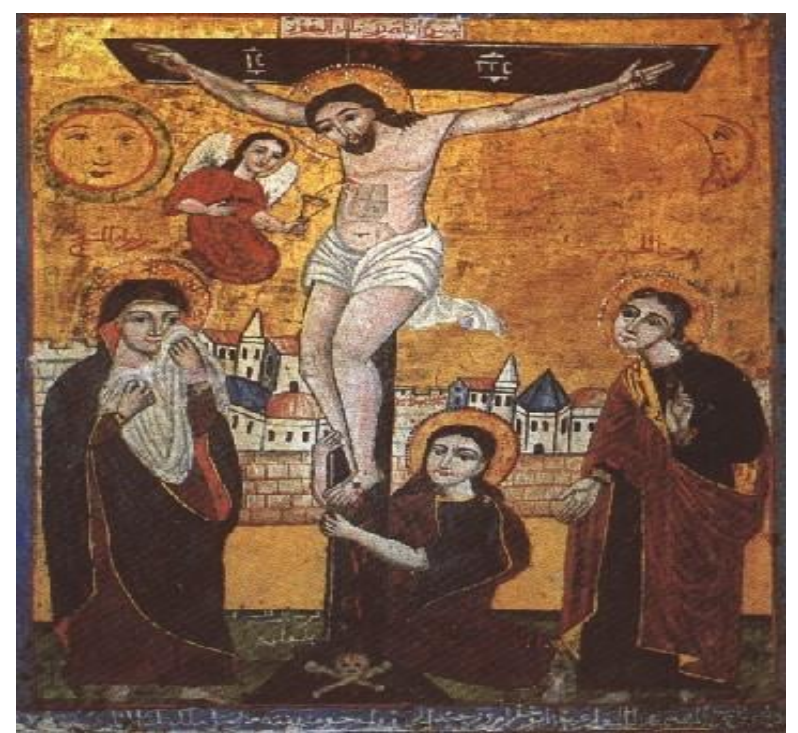

Fig.8. Icon of Crucifixion, Monastery of Mar Mina in Sanabu, Asyut. Taken by the author@Ahamd Khalaf.

\section{Gestures of wailing in entombment scenes}

The burial process of Jesus the Christ is mainly narrated in the four canonical gospels (Mark, Matthew, John, and Luke). ${ }^{1}$ The Holy Virgin attends the incident of the Christ's burial. The Coptic iconographer shows her in larger size as a prominent figure.

She stands behind the body of the Christ in a full figure. The upper part represents her raised arms up with open palms. Her head is nodding towards the right side. The most distinguished features of the face are closed small mouth and partly closed eyes.

\footnotetext{
${ }^{1}$ Mark chapter 15, verses 46-47, Matthew chapter 27, 59-61, John Chapter 19, verses 39-41, Luke chapter 23, verses 53-61.
} 


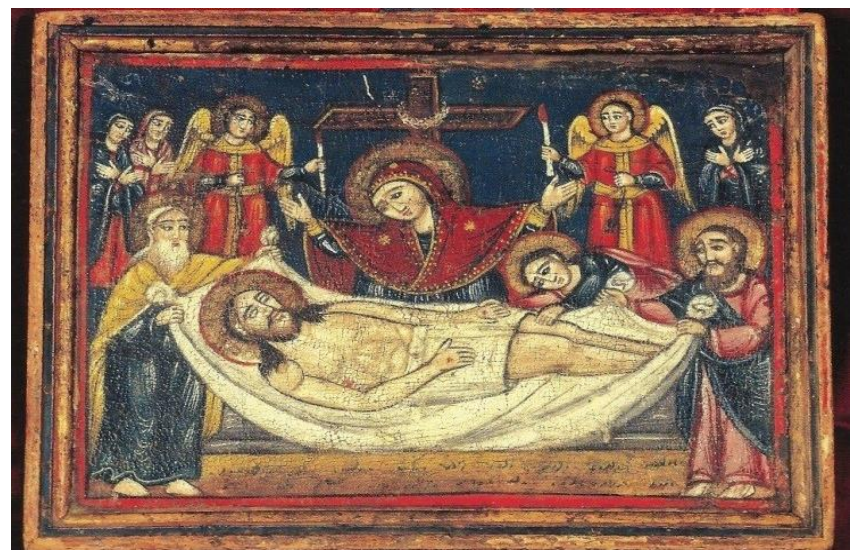

Fig. 9. Icon of the Entombment, Anistasi Al Roumy, $19^{\text {th }} \mathrm{CE}$., Church of Abu Sayfien, Akhmim, after; (Gabra and Van Loon 2007, 274)

The gestures can be explained as follows: upraising both hands and directing the head towards the right here may be interpreted as wailing attitude (Figs. 9, 10). ${ }^{1}$

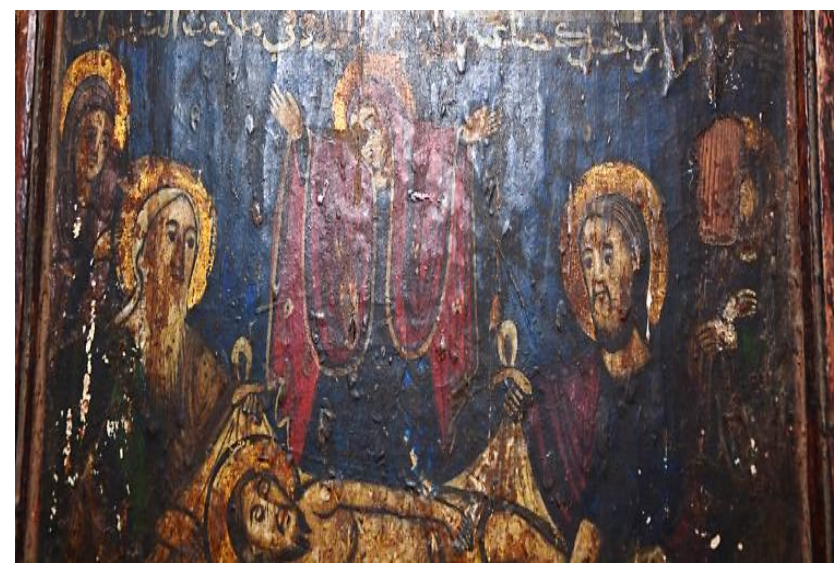

Fig.10. Detail of icon of the Entombment, Anistasi Al Roumy, $19^{\text {th }}$ CE., monastery of Al Mallak, Mallawi. Taken by the author@ Ahamd Khalaf.

\section{- Gestures of obedience and greeting during flight to Egypt}

Flight to Egypt is narrated in Mathew chapter two, verses 13:18. The iconographer presents the flight to Egypt in two stages of the journey; the first during the road before entering Egypt, and the other while it reaches Egypt.

The icon of the flight to Egypt during the road is preserved in the Coptic Museum (Fig.11). The Holy Virgin Mary is shown riding a horse. She holds rein of a horse with her left hand with closed fist, and pulls the bridle of the horse hard to control the horse. Her right hand is raised with open palm in frontal pose. Her facial expressions are her both eyes are half closed and looking in front of Her. Her moth is tightly closed. Her both legs are beside each other.

\footnotetext{
${ }^{1}$ Mayer I. Gruber, Aspects of Nonverbal Communication in the Ancient Near East (Rome: Biblical Institute Press, 1980), 401.
} 


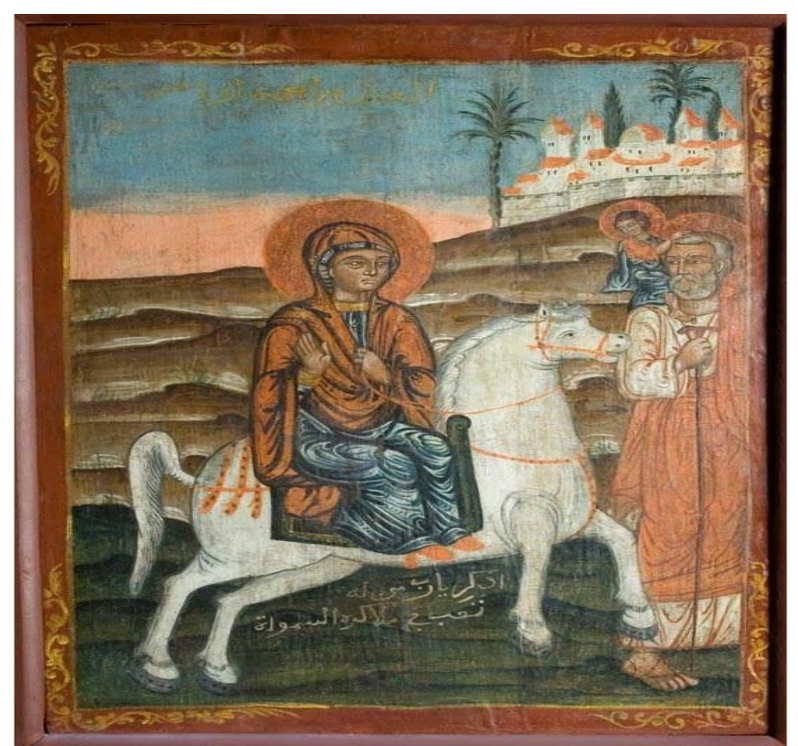

Fig.11. Journey to Egypt, Coptic Museum in Cairo. After; (Gabra and EatonKrauses 2007, 198)

In the other icon the Holy Virgin Mary is represented riding a horse. Although she must hold reins of the horse with hands, the painter shows her hands crossed over her chest with open palms. That gesture refers to the obedience of the Virgin (Fig.12).

She bends her head in reference to obedience and compliance with God's command. As nodding the head refers to the acceptance of a matter. Bowing the head is one of universal gestures of obedience. Her legs are shown beside each other. ${ }^{1}$

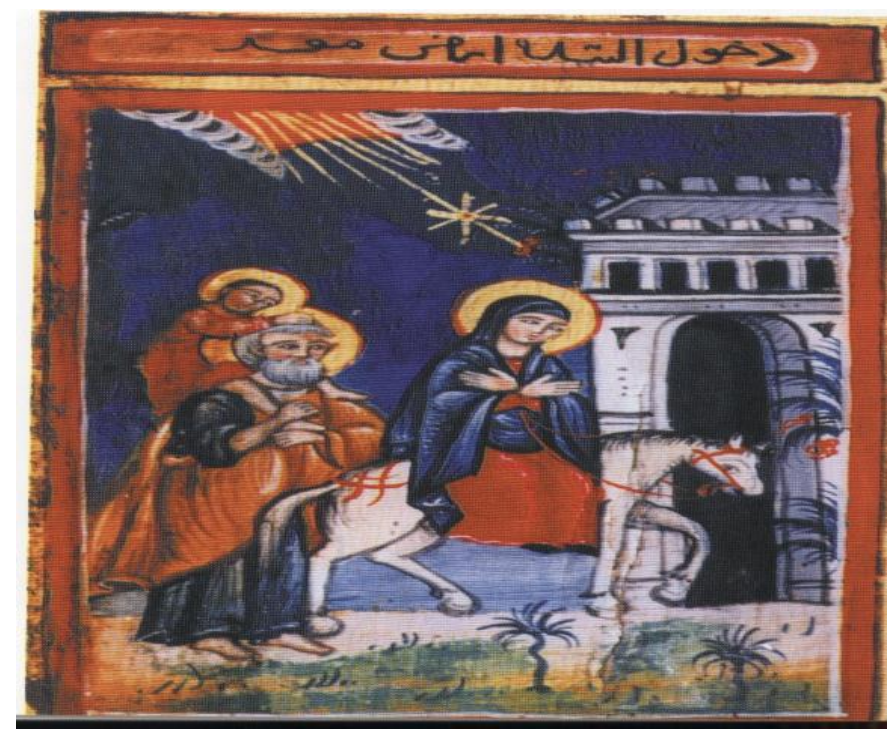

Fig.12. Arrival in Egypt preserved in the Holy Virgin Church in Maadi. After; (Skalova and Gabra., 2003, 244)

\footnotetext{
1 Pease, The Definitive Book of Body Language, 230.
} 


\section{- Gestures of falling asleep}

According to the sayings of Saint Cyril, Pope Alexander, and Pope Theophilis the 23rd, and to what was mentioned in the Coptic Church Synaxarium, the ecclesiastical tradition narrates that "She falls asleep in 21 of Tubah Month".

Falling asleep iconography, the Holy Virgin Mary appears with some non-verbal gestures as in figure 13. She lays on her back on rocky building. Her both hands are crossed above her breast; the right hand is over the left one, both of them are in back side. They are shown with open palms. It differs from the Osirian attitude, which takes a similar attitude with both crossed hands, except for the fact that here the hands are opened, while in the Osirian attitude both hands are closed fist to hold objects. Her eyes are represented closed in reference to sleep. Both legs are represented adjoining each other. Her head faces the sky.

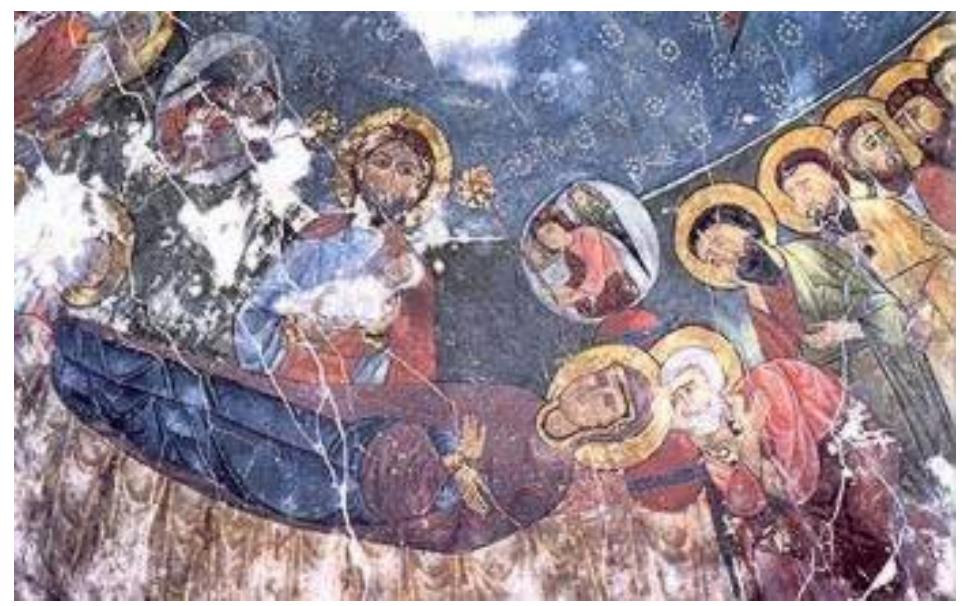

Fig.13. Dormition of the Holy Virgin Mary, Holy Virgin Mary Church, Syrians Monastery. After; (Evelyn-White 1932, 398)

\section{- Gesture of praise}

Several scenes in different attitudes show the Holy Virgin with the Twelve Apostles. A detail of the chapel VII in Bawit represents the Holy Virgin Mary standing and is accompanyied with the twelve Apostles and a local Saint (Fig. 14). ${ }^{2}$ She is shown in the middle of the scene; looking in front and both legs are adjacent. The arms of the Holy virgin are stretched and upraised with open palms up.

This is one of the most distinguished gestures of worship in Coptic art. That is called in Latin "Orans", which means the "One who is praying". Upraising hands was one of the universal signs used before the emergence of Christianity and is widely

\footnotetext{
${ }^{1}$ René Basset, "Le Synaxaire Arabe Jacobite (Mois de Toubeh et d'Amchir)," in Patrologia Orientalis, eds. R. Graffin and F. Nau (Paris: Firmin-Didot,1915), 621-624.

${ }^{2}$ Bawit locates on the west side of the river Nile, west of the Village of Dayrut El Sherif in Asyut Governorate. The site was a great Coptic community and was abandoned for unknown reason. See: M. Jean Cledant, Le Monastère et la Nécropole De Baouit, (Cairo: Imprimerie de L'Institut Français D'Archéologie Orientale, 1904), 1-8; E. Amelineau, La Géographie de L'Egypte A L' Epoque Copte (Paris: Imprimerie Nationale, 1890), 4.
} 
represented in early Christianity. Yet the orans attitude was inspired from the Holy Book. ${ }^{1}$

Raising the hands up in a refrence to worship had two interpretations and meanings; the first is that the hands point to the god in the sky, and the other is that both hands are empty asking the filling of the God. ${ }^{2}$

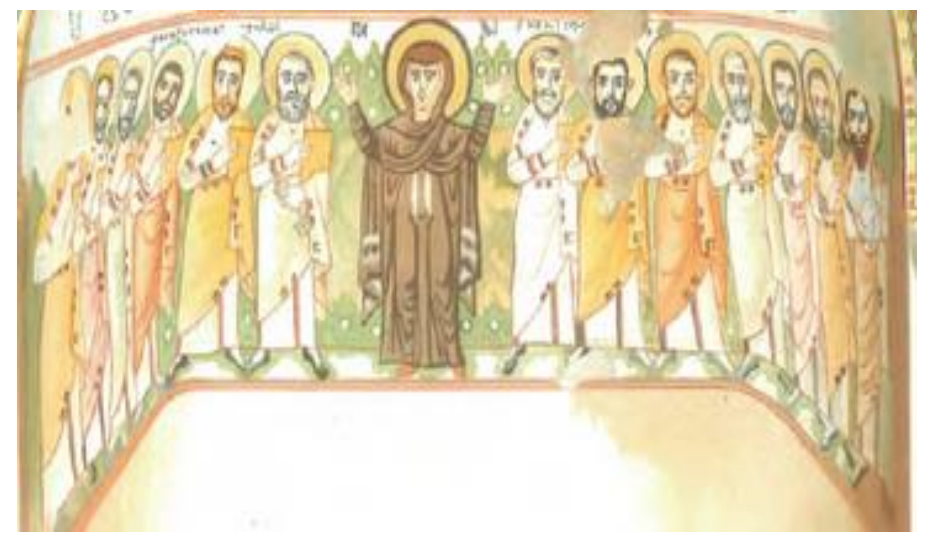

Fig.14. The Holy Virgin Mary with the Twelve Apostles and a local Saint, detail of chapel XVII, Pl. XLI. After; (Cledant 1904, 73)

\section{Conclusion}

The Coptic iconographer has successfully managed to convert the feelings inherent within the biblical text into a visual language through paintings. The Coptic iconographer widely uses the hands, head, and facial gestures to visualize the core of the theme. The head and hands are mostly used than other parts of the body to convey and express the meanings of the text and the theme.

The Holy Virgin never appears with defensive or hostile gestures such as crossing the arms and legs and putting the index finger up the check and covers the mouth with the rest fingers. The gestures reflecting astonishment, surprise, and replaying the greeting are mostly similar (Figs 1,2). The Coptic iconographer used the right hand with open palm, the head leans to the Angel in reference to listening to his speech, the eyes looking down, and both the legs are beside each other.

Feelings of fear, fatigue and hard circumstances are applied in some gestures as; lying on the back, putting the hands one in the knee and the other on the chest (Figs 3,4). The palms of the Holy Virgin are in most scenes opened. The closed hands and the upraised index finger that explores as warning sign are rarely used by Coptic iconographers in the representations of the Holy Virgin. Maternity feelings of the Holy virgin are explored by the Coptic iconographer mostly with the same gestures (Figs. 5, 6). These gestures are shown in sitting position and holding the infant Jesus on Her lab with one hand and the other is pointing to Him. Her head leans and touches the infants head. She is looking frontally in fig. 5 and looking to Him in fig.

\footnotetext{
${ }^{1}$ Psalms; 133:9, 8: 2.

${ }^{2}$ David M. Calabro, "Gestures of Praise: Lifting and Spreading the Hands in Biblical Prayer," in Ascending the Mountain of the Lord: Temple, Praise, and worship in the Old Testament, eds. David Rolph Seely, Jeffrey R. Chadwick and Matthew J. Grey (Utah: Brigham Young University, 2013), 116.
} 
6. Fear gestures can be shown clearly during the crucifixion of Jesus the Christ as in the clenched hands in front of the chest and looking up towards Him and the semi closed eyes (Fig. 7). While sadness fears can be explored through the kerchief used to dry the tears of Her (Fig. 8)

Outstretching the arms with open palms, crying eyes, and looking down are the most used gestures for representing wailing and sorrow feelings (Figs. 9, 10). The raised opened right hand is used as a sign of greeting of the Holy Virgin (Fig. 11), while crossing the hands over the chest symbolizes the obedience of the order of the God (Fig. 12). Laying to back with closed eyes, head looks up, the aligned legs and the crossed hands over the chest exposes falling asleep (Fig. 13). Also, the hands while are raised and spread is one of well-known gestures of praise to the God (Fig. 14).

The Holy Virgin is widely shown dominating and wearing long dresses in different colors and scarf also over Her head. Mostly the iconographers used the official blue and red color for Her dress. She is also dressed in brown color (Figs. 5, 8, 11). The blue is widely used as it symbolizes the sky and the royal red as she is queen and mother of the king.

\section{Bibliography}

- Allan, Pease and Barbara Pease. The Definitive Book of Body Language. London: Orion Media Press, 2004.

- Amelineau, Émile. La Géographie de L'Egypte à L'Epoque Copte, Imprimerie Nationale, Paris: Imprimerie Nationale, 1890.

- $\quad$ Basset, René. "Le Synaxaire Arabe Jacobite (Mois de Toubeh et d'Amchir)," in Patrologia Orientalis, eds. R. Graffin and F. Nau, 621-624. Paris: FirminDidot, 1915.

- Bockmuehl, Markus. Ancient Apocryphal Gospels, Louisville, Kentucky: Westminster John Knox Press, 2017

- Botha, J. Eugene. "Exploring Gesture and Nonverbal Communication in the Bible and the Ancient World: Some Initial Observations," Neotestamentica, Vol. 30, Issue 1, December 1960.

- Calabro, David M. "Gestures of Praise: Lifting and Spreading the Hands in Biblical Prayer," in Ascending the Mountain of the Lord: Temple, Praise, and worship in the Old Testament, eds. David Rolph Seely, Jeffrey R. Chadwick and Matthew J. Grey, Utah: Brigham Young University, 2013.

- Cledant, M. Jean. Le Monastère Et La Nécropole De Baouit, Cairo: Imprimerie de L'Institut Français D'Archéologie Orientale, 1904.

- Du Bourguet, Pierre, "Christian Subjects in Coptic Art," in Coptic Encyclopedia, ed. Aziz S, Atiya. New York: Macmillan Publishing Company, 1991, Vol. II, 526-544.

- El Gendi, Sherin Sadek "Different Attitudes of The Holy Virgin Mary In Coptic Art," دراسات في آثار الوطن العربي, Vol.13, Issue 13, 2010.

- Evelyn-White, Hugh G. The Monastries of Wadi 'N Natrun: Architecture and Archaeology, Part II, New York: MCMXXXIII Publisher, 1932. 
- Gabra, Gawdat and Eaton-Krauss, Marianne. The Illustrated Guide to the Coptic Museum and Churches of Old Cairo, Cairo. New York: The American University in Cairo Press, 2007.

- Gabra, Gawdat and Van Loon, Gerturd J.M. The Churches of Egypt from the Journey of the Holy Family to the Present Day, Cairo-New York: The American University in Cairo Press, 2007.

- Givens, David B. The Nonverbal Dictionary of Gestures, Signs and Body Language Cues, Washington: Center for Nonverbal Studies Press, 2002.

- Mayer I. Gruber Aspects of Nonverbal Communication in the Ancient Near East, Rome: Biblical Institute Press, 1980.

- Schildkrout, Enid. "Body Art as Visual Language," AnthroNotes, Vol. 22, (Winter 2001).

- Skalova, Zuzana and Gawdat Gabra. Icons of the Nile Valley, Cairo: Egyptian International Publishing Company-Longman. 2006.

- The Holy Book, New Testament.

- Zibawi, Mahmoud. Images de L'Egypte Chrétienne: Iconologie Copte, Paris, J. Picard Press, 2003.

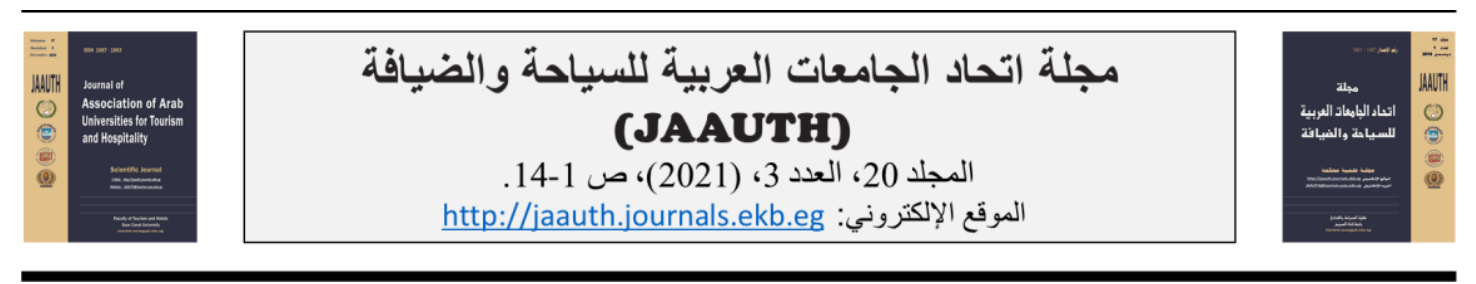

\section{لغة جسد السيدة العذراء مريم في التصوير القبطي أحمد محمد خلف \\ كلية السياحة والفنادق، جامعة المنيا.}

\begin{tabular}{|c|c|}
\hline الملخص & معلومات المقالة \\
\hline 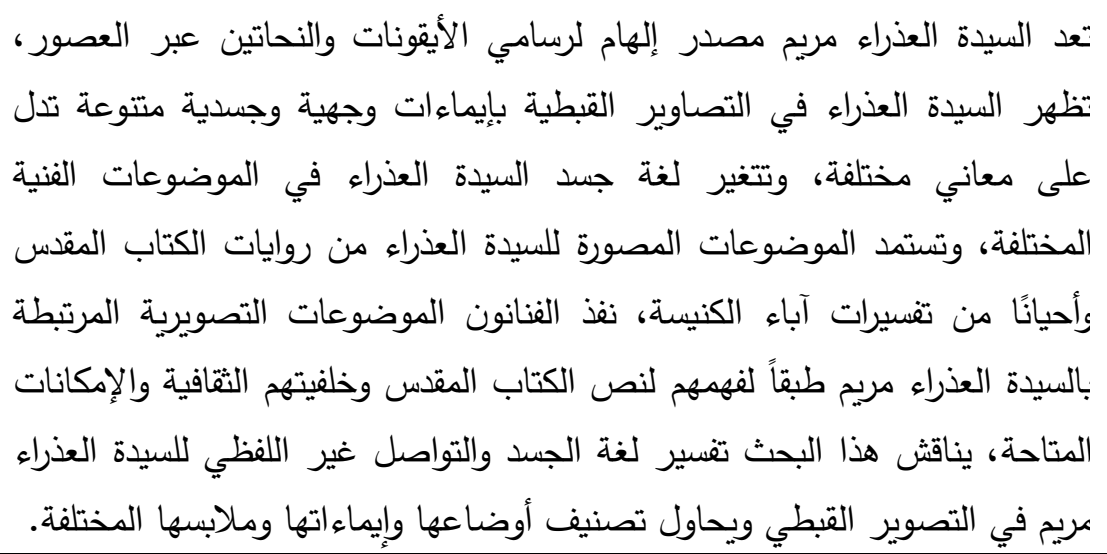 & 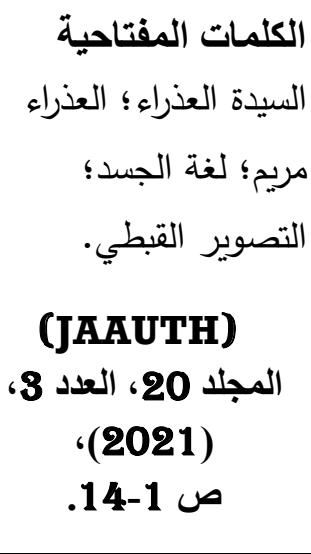 \\
\hline
\end{tabular}

